\title{
Influence of Process Parameters on Copper Content in Reduced Iron Silicate Slag in a Settling Furnace
}

\author{
Jenny Isaksson ${ }^{1, * \mathbb{D}}$, Tommy Vikström ${ }^{2} \mathbb{D}$, Andreas Lennartsson ${ }^{1} \mathbb{D}$ and Caisa Samuelsson ${ }^{1}$ \\ 1 Department of Civil, Environmental and Natural Resources Engineering, Luleå University of Technology, \\ 97187 Luleå, Sweden; andreas.lennartsson@ltu.se (A.L.); caisa.samuelsson@ltu.se (C.S.) \\ 2 Process Development, Boliden Rönnskär, Rönnskärsverken, 93281 Skelleftehamn, Sweden; \\ tommy.vikstrom@boliden.com \\ * Correspondence: jenny.isaksson@ltu.se; Tel.: +46-73-825-31-60
}

Citation: Isaksson, J.; Vikström, T.; Lennartsson, A.; Samuelsson, C. Influence of Process Parameters on Copper Content in Reduced Iron Silicate Slag in a Settling Furnace. Metals 2021, 11, 992. https://doi.org/ $10.3390 /$ met11060992

Academic Editors: Alexander Ivanovich Zaitsev and Lauri Holappa

Received: 6 May 2021

Accepted: 18 June 2021

Published: 21 June 2021

Publisher's Note: MDPI stays neutral with regard to jurisdictional claims in published maps and institutional affiliations.

Copyright: (c) 2021 by the authors. Licensee MDPI, Basel, Switzerland. This article is an open access article distributed under the terms and conditions of the Creative Commons Attribution (CC BY) license (https:/ / creativecommons.org/licenses/by/ $4.0 /)$.

\begin{abstract}
During the pyrometallurgical extraction of copper, a significant fraction of this metal is lost with discard slag, which decreases profits and overall copper recovery. These copper losses can be reduced by using a settling furnace, in which suspended droplets containing copper separate from slag under the influence of gravity. An industrial trial was conducted in a settling furnace to increase the knowledge of the effect of temperature and settling time on the copper content of slag, and thus enhance the settling process to increase copper recovery. Slag samples were collected from four sample points: the ingoing and outgoing slag stream, within the furnace during settling, and the granulated slag. The chemical composition of the slag samples was analyzed and compared between batches with different temperatures and settling times. The appearance of copper and its associated phases were analyzed using a scanning electron microscope with an energy-dispersive X-ray spectroscopy detector (SEM-EDS). The results indicated that the outgoing slag copper content increased with an increase in temperature, and it was also concluded to be influenced by the attachment of copper to spinels and gas bubbles. The results indicate that regulating the settling furnace temperature to a lower interval could increase copper recovery.
\end{abstract}

Keywords: copper losses; temperature; settling time; industrial trial; solid phases; slag cleaning; gas bubbles; fayalite slag

\section{Introduction}

Copper losses to slag limit overall recovery and, thus, decrease the profit and efficiency of raw material usage during pyrometallurgical copper extraction. The copper in slag is either dissolved or mechanically entrained as matte or metallic droplets. Slag generated in a smelting furnace often has a copper content of 1-2 wt\% [1], which can be partly recovered by slag-cleaning operations. However, the copper content in discarded slag is still often higher than that of sulfidic copper ores. Thus, the investigation of copper losses to slag can help to reduce these losses and is, therefore, a task of high practical significance. Challenges during slag-cleaning operations involving a settling furnace include predicting the settling time of entrained copper and the optimal conditions for the maximum settling rate.

At the Boliden Rönnskär smelter in Sweden, sulfidic copper concentrates are either roasted and smelted in an electric smelting furnace (ESF) or smelted in an Outokumpu flash furnace. The ESF is also charged with secondary material, flux, and converter slag returns. The slag generated by the ESF is transferred to a zinc fuming furnace (ZFF), which is mainly used for the extraction of zinc through its reduction with pulverized coal in the presence of air [2]. The fumed slag is tapped into an electric settling furnace where the entrained copper, in the form of matte and speiss, can separate under the action of gravity. Speiss is a metalloid containing copper, arsenic, antimony, tin, and nickel. Subsequently, the settled copper phases are tapped from the settling furnace and thus recovered. 
Already, several factors have been suggested to influence the content of the entrained copper in slag, with most of the studies being experiments with synthetic slag with an $\mathrm{Fe} / \mathrm{SiO}_{2}(\mathrm{wt} \% / \mathrm{wt} \%)$ ratio that exceeds or equals 1.2. The copper content in slag is dependent on external factors such as tapping, charging, and turbulence caused by e.g., gas injections. Minto and Davenport claimed that copper entrainment is partly caused by the production of $\mathrm{SO}_{2}$ bubbles, where matte can lay as a surface film on the bubble when it rises through the slag [3]. The same phenomena, of copper attached to gas bubbles, have been observed in several studies [4-7]. In other words, matte can be carried through the matte-slag interface and become dispersed as matte droplets when the surface film ruptures.

The entrainment of copper can also be caused by the precipitation of copper due to decreased solubility in slag [8]. Precipitated metallic copper becomes dispersed as fine droplets that take a long time to settle, which limits copper recovery. Dissolved copper can also be reduced into liquid metallic copper upon slag reduction, which could be a part of slag-cleaning. A drawback of the presence of metallic copper in slag is that it tends to retain impurities such as arsenic, antimony, and bismuth from the slag $[9,10]$. Dissolved copper could also precipitate upon slag quenching [11,12], which makes it complex to determine if the copper in solidified slag originated as dissolved or entrained copper in the molten slag.

Chemically dissolved copper associates with oxide $\left(\mathrm{O}^{2-}\right)$ or sulfide $\left(\mathrm{S}^{2-}\right)$ and is distributed within the slag matrix [13]. According to Zhao et al., copper cations can dissolve in fayalite [14], which is often the major phase of copper slag. Solubility depends on matte grade [15-18], oxygen partial pressure [19,20], slag composition [21,22], and temperature. Currently, the correlation between copper solubility and temperature is under debate. Mackey has stated that oxidic copper solubility in general increases with an increase in the partial pressure of oxygen, and temperature [13]. In a thermodynamic assessment by Shishin et al., it was shown that the copper content in slag (Cu-Fe-O-S-Si system) is at its maximum at intermediate matte grades, then falls slightly and rises again when approaching $80 \mathrm{wt} \%$ copper in the matte. The curve of the copper content in the slag at different matte grades was shifted towards a higher slag copper content when the temperature was increased [15].

However, Toguri and Santander investigated the behavior of a copper-gold alloy in a silica-saturated fayalite slag, suggesting that the copper solubility decreases with increasing temperatures [23]. Zivkovic et al. claimed that the slag copper content increased with decreasing temperatures in a reverberatory furnace because of the concomitantly increasing slag viscosity and the long stratification time within the furnace [6]. The lack of agreement on the correlation between copper solubility and temperature probably reflects the difficulty of determining the state of copper (i.e., chemically dissolved, mechanically entrained, or both) in slag. Moreover, temperature is known to affect settling behavior as it, e.g., affects viscosity [24-26] and the appearance of solid phases.

Settling processes can also be hindered by the attachment of copper to solid phases, as suggested in experimental studies by Bellemans et al. and De Wilde et al. [27-30]. Copper attached to spinels has a lower density than the underlying copper phase and thus cannot settle completely [29]. The copper spinel entity could instead accumulate at the bottom of the slag layer above the settled copper phases.

Sukhomlinov et al. studied chromium solubility in iron silicate slags, suggesting that a chromite spinel could precipitate when the chromium content exceeded the solubility [31]. The chromite spinel phase is denser compared to the slag phase, which leads to the accumulation of chromium in the furnace. According to Lennartsson et al., the ESF at the Boliden Rönnskär smelter has a bottom buildup comprising of spinel, matte, olivine, and metalloids, where the dominating phase was identified as spinel [32]. Spinels are thus a possible solid phase in the ESF slag, which could hinder copper from settling. Currently, existing literature lacks information on the settling of copper in ESF slags (with an $\mathrm{Fe} / \mathrm{SiO}_{2}$ ratio of close to equal) that is treated in a $\mathrm{ZFF}$, and then tapped into a settling furnace. It is 
thereby of interest to investigate how the mentioned phenomena influence settling and slag copper content on an industrial scale.

Given the above, a project was initiated to obtain fundamental insights into the mechanism of settling in slag. An industrial trial was conducted in the settling furnace at the Boliden Rönnskär smelter to increase the knowledge of the slag system and to determine the effects of temperature and settling time on slag copper content. The slag was characterized to determine the appearance of copper and its associated phases. Increased settling rates result in higher copper recovery, higher profits, and the increased efficiency of raw material usage.

\section{Materials and Methods}

\subsection{Electric Settling Furnace Description}

The electric settling furnace at Boliden Rönnskär is operated batch wise and charged with ZFF slag through a funnel located at the furnace roof, close to one of the short sides. The funnel can be seen to the right in Figure 1a, which presents a schematic of the furnace. The settling furnace is rectangular with a rounded bottom. The tap hole for outgoing slag is located opposite the charging funnel, and the tap hole for the copper phases is located in the center of one of the long sides. The temperature in the settling furnace is regulated by changing the voltage and submerged depth of four graphite electrodes submerged into the slag layer.
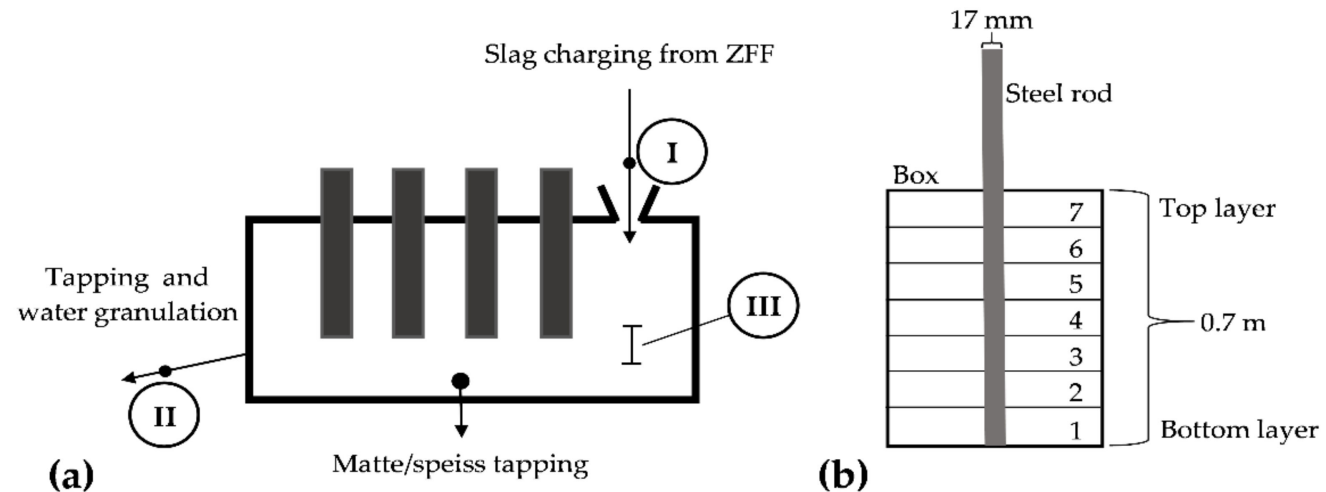

(b)

Figure 1. (a) Schematic of the settling furnace at Boliden Rönnskär smelter, where "I" and "II" mark ingoing and outgoing slag collection, respectively, and the line within the furnace denotes the position of the vertical slag sample, "III"; (b) schematic of the steel rod and box used to divide vertical slag samples. The bottom slag layer corresponds to level 1, the second-lowest to level 2, etc.

During operation, a buildup in the form of solidified phases accumulates at the furnace bottom. During the evaluated trial, the buildup height increased towards the short sides, where the buildup contacted the slag layer, and was lowest in the middle, where the copper phases accumulate. The slag is kept in the settling furnace without any tapping while matte and speiss settle to the furnace bottom. The copper phases are accumulated from several batches and tapped once a day. The slag, which remains after the settling time, is tapped and granulated with water-jets, and then pumped to dewatering basins.

\subsection{Experimental Design and Sampling}

The industrial trial was conducted in an electric settling furnace at various temperatures and settling times. The settling time, defined as the time between the finalization of charging and the tapping start, was targeted to equal $15 \mathrm{~min}, 30 \mathrm{~min}$, and $60 \mathrm{~min}$, resulting in a total operating time of 75-120 min (including the settling time and tapping out of the furnace). The temperature was measured in the slag stream when the slag tapping out of the furnace started. In total, ten different batches (T1-T10) from the trial were evaluated, where the settling times were targeted to equal $30 \mathrm{~min}$ for T1-T4, 15 min for T5-T7, and 
$60 \mathrm{~min}$ for T8-T10. The three to four batches at each settling time were targeted to have a low, middle, and high temperature in the settling furnace.

The intervals of the main compounds in the ESF slag after reduction in the ZFF are described in Table 1 . The interval given in Table 1 describes the evaluated batches, excluding minor elements below $1 \mathrm{wt} \%$, and copper.

Table 1. Main components of the settling furnace slag.

\begin{tabular}{cccccc}
\hline \multicolumn{7}{c}{$[\mathbf{w t} \%]$} \\
\hline $\mathrm{SiO}_{2}$ & $\mathrm{FeO}$ & $\mathrm{Al}_{\mathbf{2}} \mathrm{O}_{3}$ & $\mathrm{CaO}$ & $\mathrm{MgO}$ & $\mathrm{ZnO}$ \\
\hline $36-39$ & $48-50$ & $4.4-5.4$ & $3.4-4.7$ & $1.3-1.9$ & $0.7-1.6$ \\
\hline
\end{tabular}

In total, four sample points (ingoing, outgoing, vertical, and granulated slag) were used as the basis for the evaluation of the copper content in the settled slag. Multiple sample points were evaluated as the entrained copper phases may not be homogeneously distributed within the slag layer, which in turn influences the copper analysis.

For the collection of the ingoing slag sample ("I" in Figure 1a), steel scoops were lowered into the slag stream during the tapping from the ZFF to the settling furnace and cooled in the ambient air. The ingoing slag samples were collected at 5 min intervals, resulting in three samples (beginning, middle, and end of the tapping). The outgoing slag sample collection ("II" in Figure 1a) was performed in the same way as the ingoing slag collection but at 15-min intervals, resulting in five to six samples per batch. An additional sample representing the batch was intermittently collected during the water granulation. An ejector pump was used to collect the sample from the granulation tank, where the granulated slag is collected before pumping the granules to the dewatering basins.

Vertical slag samples ("III" in Figure 1a) were collected from within the furnace by lowering a steel rod into the slag layer through the charging funnel. The steel rod was lowered to the depth where it touched the bottom buildup to ensure that the entire slag layer was represented. The sample was cooled in the ambient air. The slag thickness on the steel rod was estimated to be $\sim 5 \mathrm{~mm}$, resulting in fast cooling. The solidified sample on the steel rod was held over a box and divided into levels numbered 1-7 (see Figure 1b), where each level had a height of $\sim 0.1 \mathrm{~m}$. Slag from the bottom layer corresponds to level 1. The slag from the top layer corresponds to level 6 or 7, depending on the slag amount in the furnace and the height of the bottom buildup. A schematic of the steel rod and box is shown in Figure $1 b$.

Batches T1-T4 were selected to further study the influence of temperature on the copper content in the vertical slag samples, as these batches featured similar ingoing copper contents and an approximately equal settling time. The levels analyzed were levels 1, 2, 3, and the second-highest level, which was level 5 or 6 . An overview of the trial parameters, batches, samples, and methods used are presented in Table 2.

An average of the copper content in the ingoing, outgoing, and vertical slag samples (levels 2, 3, and 5 or 6) was calculated. The level 1 samples were excluded from the average copper content calculation, as that sample represents the bottom slag layer, which was above the bottom buildup during sampling. The influences of the temperature and settling time were evaluated by comparing the copper content of the ingoing slag samples with that of the outgoing, vertical, and water-granulated slag samples. 
Table 2. Overview of the trial including slag characterization and the evaluation of process parameters temperature (temp.), settling time (time), batches, and sample analysis.

\begin{tabular}{|c|c|c|c|c|c|c|c|}
\hline \multirow{2}{*}{$\begin{array}{l}\text { Experimental } \\
\text { Overview }\end{array}$} & \multirow[b]{2}{*}{ Parameter } & \multirow[b]{2}{*}{ Batch } & \multirow[b]{2}{*}{ Sample } & \multicolumn{4}{|c|}{ Analysis } \\
\hline & & & & XRF & FAAS * & ICP-SFMS & SEM-EDS \\
\hline $\begin{array}{c}\text { Slag } \\
\text { Characterization }\end{array}$ & Temp. & $\mathrm{T} 1, \mathrm{~T} 2, \mathrm{~T} 4$ & Level & & & $x$ & $x$ \\
\hline \multirow[t]{2}{*}{$\begin{array}{l}\text { Process } \\
\text { Parameter }\end{array}$} & Temp. & $\mathrm{T} 1-\mathrm{T} 4$ & $\begin{array}{l}\text { Ing. } \\
\text { Level } \\
\text { Out. } \\
\text { W.g. }\end{array}$ & $\begin{array}{l}x \\
x \\
X\end{array}$ & $\begin{array}{l}x \\
x\end{array}$ & $x$ & \\
\hline & Temp. and time & T1-T9 & $\begin{array}{l}\text { Ing. } \\
\text { Out. } \\
\text { W.g. }\end{array}$ & $\begin{array}{l}X \\
X \\
X\end{array}$ & $\begin{array}{l}x \\
X\end{array}$ & & \\
\hline
\end{tabular}

${ }^{*} \mathrm{Cu}$ content in the samples.

\subsection{Experimental Procedure}

Samples of ingoing, outgoing, and water-granulated slag were analyzed in the smelter laboratory at Boliden Rönnskär with their standardized method using a Philips PW2606 X-ray fluorescence (XRF) instrument (Malvern Panalytical, Malvern, UK). The copper content of the ingoing and outgoing slag samples was determined by an Agilent $280 \mathrm{FS}$ AA instrument (flame atomic absorption spectroscopy) (Agilent Technologies, Santa Clara, UK) in the same laboratory. Vertical slag samples collected at the settling start and end were analyzed at a certified laboratory (ALS Scandinavia AB, Luleå, Sweden) using a Thermo Finnigan Element 1 inductively coupled plasma-sector field mass spectroscopy instrument (ICP-SFMS) (Thermo Fisher Scientific, Waltham, MA, USA). Before the ICP-SFMS analysis, the samples were digested using two different methods. The oxides $\mathrm{SiO}_{2}, \mathrm{FeO}_{2} \mathrm{Al}_{2} \mathrm{O}_{3}, \mathrm{CaO}$, $\mathrm{MgO}$, and $\mathrm{Cr}$ were analyzed in a solution obtained from fusion with lithium metaborate and digestion in nitric acid. $\mathrm{Cu}, \mathrm{Pb}, \mathrm{Zn}$, and $\mathrm{Sb}$ were analyzed in a solution where the sample was digested in a mixture of nitric acid, hydrochloric acid, and hydrofluoric acid during heating. Iron, chromium, lead, and zinc contents were recalculated as oxides. The results of all the slag compositions were normalized to the total sum of $100 \mathrm{wt} \%$. The copper content in the ingoing, outgoing, and vertical slag samples is presented as an average with an error equaling \pm one standard deviation.

The phases in the vertical slag samples were determined using a Zeiss Gemini Merlin scanning electron microscope (SEM) (Zeiss, Oberkochen, Germany) after the samples had been mounted in epoxy, polished, and carbon coated. The phases were analyzed quantitatively using an Oxford Instruments X-Max energy-dispersive X-ray spectroscopy (EDS) (Oxford Instruments, Abingdon, UK) detector at an accelerating voltage of $20 \mathrm{keV}$, an emission current of $1 \mathrm{nA}$, and a working distance of $8.5 \mathrm{~mm}$. Prior to the analysis, the beam measurement calibration for the EDS was performed on pure copper. The elemental compositions were reported in $\mathrm{wt} \%$ and normalized, meaning that the sum of the elements became $100 \mathrm{wt} \%$.

The copper recovery to the settled copper phases was calculated according to Equation (1), where $\% C u_{\text {in }}$ is the average weight percent of copper in the ingoing slag, and $\% C u_{\text {out }}$ is an average of the weight percent of copper in the water-granulated and the average outgoing slag. The difference in mass of the ingoing slag and outgoing slag was assumed to be negligible.

$$
\text { Copper recovery }[\%]=100 \% \cdot \frac{\% C u_{\text {in }}-\% C u_{o u t}}{\% C u_{\text {in }}}
$$




\section{Results and Discussion}

\subsection{Effect of Temperature in the Settling Furnace}

The copper content in the batches with varying temperatures and settling times is shown in Table 3. The temperatures varied between $1210{ }^{\circ} \mathrm{C}$ and $1288^{\circ} \mathrm{C}$, taking all 10 batches into account. The ingoing copper contents varied between $1.02 \mathrm{wt} \%$ and $1.55 \mathrm{wt} \%$. The settling time was between $28 \mathrm{~min}$ and $36 \mathrm{~min}$ for T1-T4, $13 \mathrm{~min}$ and $14 \mathrm{~min}$ for T5-T7, and $59 \mathrm{~min}$ and $62 \mathrm{~min}$ for T8-T10. The individual analyses of the evaluated batches can be found in Table A1, Appendix A. The Fe/ $\mathrm{SiO}_{2}$ ratio in the slag varied between 0.97 and $0.99(\mathrm{wt} \% / \mathrm{wt} \%)$, which was based on the analysis of the water-granulated slag.

Table 3. The settling time, temperature, and average copper contents in ingoing (ing.), outgoing (out.), and vertical (avg. levels) slag samples, and the copper content in the water-granulated slag (w.g.). The complete compositions for the samples are found in Table A1.

\begin{tabular}{ccccccc}
\hline \multirow{2}{*}{ Batch } & {$[\mathbf{m i n}]$} & {$\left[{ }^{\circ} \mathbf{C}\right]$} & \multicolumn{4}{c}{$[\mathbf{C u}$ Content, wt $\%]$} \\
\cline { 2 - 6 } & Settling Time & Temp. & Ing. & Out. & W.g. & Avg. Levels \\
\hline T1 & 32 & 1276 & 1.14 & 0.63 & 1.25 & 1.21 \\
T2 & 28 & 1264 & 1.32 & 0.85 & 1.00 & 0.90 \\
T3 & 35 & 1252 & 1.02 & 0.62 & 0.71 & 0.55 \\
T4 & 36 & 1210 & 1.03 & 0.46 & 0.55 & 0.58 \\
T5 & 13 & 1265 & 1.39 & 0.79 & 1.01 & - \\
T6 & 14 & 1256 & 1.21 & 0.82 & 0.77 & - \\
T7 & 13 & 1227 & 1.55 & 0.66 & 0.67 & - \\
T8 & 59 & 1288 & 1.35 & 0.83 & 0.93 & - \\
T9 & 62 & 1251 & 1.20 & 0.78 & 0.67 & - \\
T10 & 59 & 1215 & 1.29 & 0.63 & 0.53 & - \\
\hline
\end{tabular}

Figure 2a shows the effect of the temperature on the copper contents for batches T1-T4 (settling time $\sim 30 \mathrm{~min}$ ). The copper content is the average content in the outgoing slag, the vertical slag samples, and the water-granulated slag, revealing that the slag copper content increased with increasing temperatures. Notably, for T1, the copper content was higher in the water-granulated slag and the average of the vertical slag samples compared to the average outgoing slag. The copper content in the water-granulated slag of batches $\mathrm{T} 2, \mathrm{~T} 3$, and $\mathrm{T} 4 \mathrm{was} 1.00 \mathrm{wt} \%, 0.71 \mathrm{wt} \%$, and $0.55 \mathrm{wt} \%$, respectively. Figure $2 \mathrm{~b}$ presents the copper recovery in the settling furnace for batch T1-T4, which was calculated according to Equation (1). The copper recovery to the copper phases increases with decreasing temperatures, from $17.5 \%$ in $\mathrm{T} 1$ to $51.2 \%$ in $\mathrm{T} 4$.
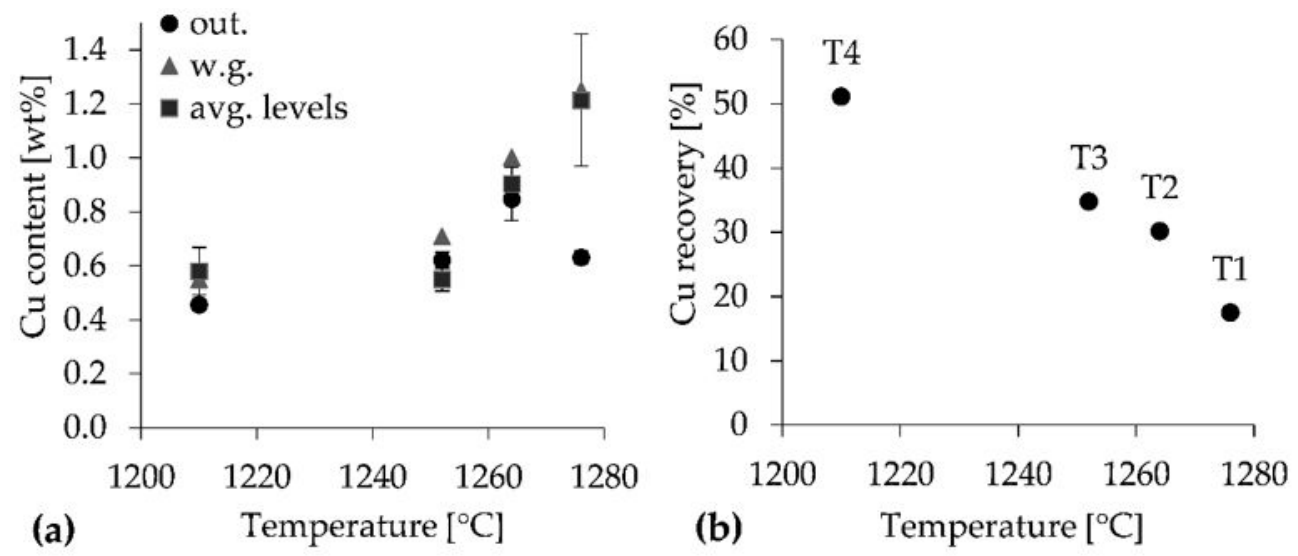

Figure 2. (a) Effect of the temperature on the copper content of average outgoing (out.), vertical slag (avg. levels), and water-granulated slag (w.g.) samples when the settling time was $30 \mathrm{~min}$; (b) copper recovery in the settling furnace versus the temperature. 
The literature revealed that copper solubility in slag increases with increasing temperatures $[13,15]$. Copper in the form of, e.g., copper oxide, cannot settle, as the copper phase is dissolved in the slag matrix. The viscosity of slag is also influenced by the temperature, where the viscosity decreases with increasing temperatures [24-26]. In the case of T1, which had a higher temperature compared to $\mathrm{T} 4$, the viscosity of the slag should be lower, which means a higher settling rate of the copper-containing droplets, and thus decreased copper content in the slag. However, the smaller droplets, which often are larger in number, could be less affected by the decreased slag viscosity as they, either way, have a long settling time. The final copper content in batches with higher temperatures could thus have been more affected by increased copper solubility than by the decreased viscosity.

The copper content in the vertical slag samples collected at the settling start and end is shown in Table 4. The compositions of all the vertical slag samples are presented in Table A2, Appendix A. At a given temperature, the highest copper content was observed at level 1 within a given batch, which indicates the settling of copper towards the bottom of the slag layer but not entirely reaching the underlying copper phase. The copper content at level 1 for $\mathrm{T} 1$ and $\mathrm{T} 2$ was $2.62 \mathrm{wt} \%$ and $2.22 \mathrm{wt} \%$, respectively, which significantly exceeded the values obtained for $\mathrm{T} 3$ and $\mathrm{T} 4(0.74 \mathrm{wt} \%$ and $0.76 \mathrm{wt} \%)$, all at the settling end.

Table 4. The copper content in vertical slag samples of batch T1-T4, collected at the settling start and end. The complete compositions of the samples are found in Table A2.

\begin{tabular}{cccccc}
\hline & & \multicolumn{4}{c}{ [Cu Content, wt \%] } \\
\hline \multirow{2}{*}{ Batch } & Settling & Level 5/6 & Level 3 & Level 2 & Level 1 \\
\hline \multirow{2}{*}{$\mathrm{T} 1$} & Start & 1.19 & 0.78 & 0.76 & 1.04 \\
& End & 1.15 & 0.95 & 1.54 & 2.62 \\
\hline \multirow{2}{*}{$\mathrm{T} 2$} & Start & 0.84 & 0.84 & 1.26 & 1.55 \\
& End & 0.87 & 0.85 & 0.99 & 2.22 \\
\hline \multirow{2}{*}{$\mathrm{T} 3$} & Start & 2.01 & 1.40 & 1.81 & 0.93 \\
& End & 0.49 & 0.57 & 0.59 & 0.74 \\
\hline \multirow{2}{*}{$\mathrm{T} 4$} & Start & 0.98 & 1.11 & 0.83 & 0.97 \\
& End & 0.55 & 0.49 & 0.70 & 0.76 \\
\hline
\end{tabular}

At a given level, the copper content at the settling start was higher than that at the settling end for T3 and T4. The opposite situation was observed for T1, where the copper content at the settling end was higher compared to the settling start. This trend was observed for levels 1-3 in T1, and levels 6, 3, and 1 in T2, indicating that the copper phases were prevented from settling. Parts of the copper phases could have dissolved in the slag layer for batches $\mathrm{T} 1$ and $\mathrm{T} 2\left(1276{ }^{\circ} \mathrm{C}\right.$ and $1264^{\circ} \mathrm{C}$, respectively).

Figure 3 a shows the effect of temperature on the copper content of the water-granulated slag subjected to settling times of between $13 \mathrm{~min}$ and $62 \mathrm{~min}$. The slag copper content increased with increasing temperatures, indicating that the copper content was more strongly correlated with the temperature than with the settling time. The effect of the settling time was in line with other studies, suggesting the rapid separation and settling of matte droplets within the first 10-15 min due to the density difference between the copper and slag phases. After $15 \mathrm{~min}$, other physical properties, such as viscosity and surface tension, were suggested to become rate-determining and the copper phase needs to form big enough droplets to settle $[33,34]$. The majority of the final copper content is thus obtained within the first $15 \mathrm{~min}$. 

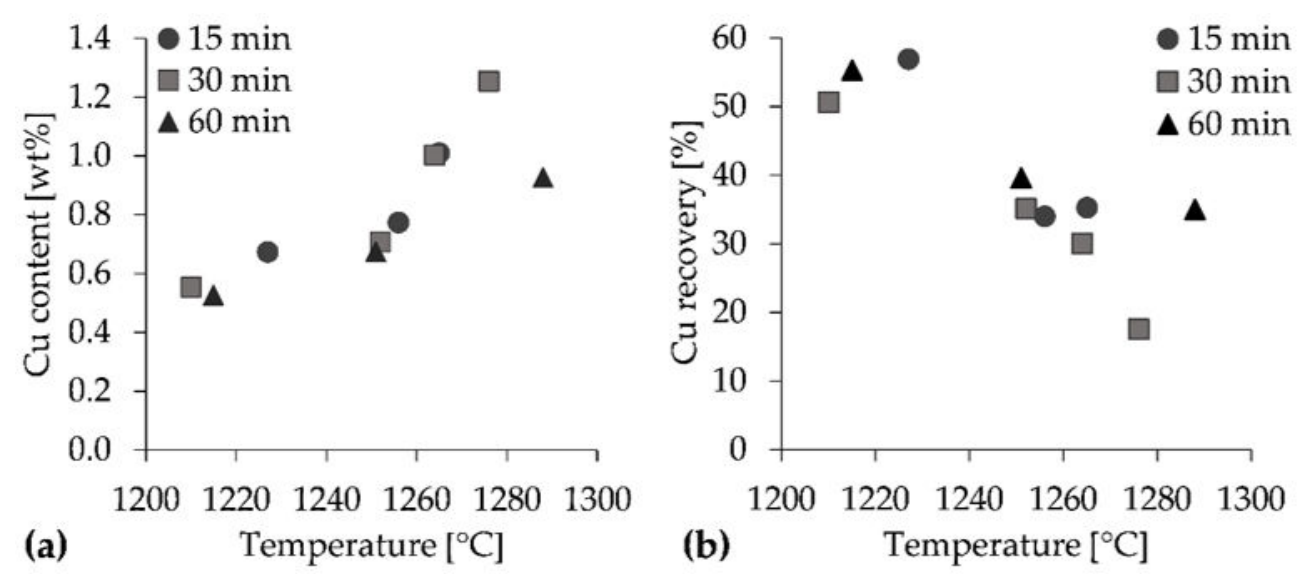

Figure 3. (a) The copper content of water-granulated slag as a function of temperature for batch $\mathrm{T} 1-\mathrm{T} 10 ;(\mathbf{b})$ the copper recovery in the settling furnace versus the temperature.

Figure $3 \mathrm{~b}$ presents the copper recovery to the settled copper phases at different temperatures and settling times. In general, copper recovery decreases with increasing temperatures, independent of the settling time. The correlation observed in Figure $3 a, b$ confirmed the effect of temperature on slag copper content in industrial slag cleaning, which was also observed in Figure 2a,b. The increased copper content of slag could be due to the elevated content of dissolved copper, which did not settle. This hypothesis was supported by the review by Mackey [13] and the results from Shishin et al. [15], where the dissolved slag copper content increased with increasing temperatures.

\subsection{Slag Characterization}

Slag samples from the industrial trial in the settling furnace at the Boliden Rönnskär smelter were characterized with SEM-EDS to increase the knowledge of the distribution of copper within the slag, and whether any factors hinder the copper-containing phases from settling. The correlation between the copper content and the content of some elements in the slag was also evaluated. Figure 4 presents SEM images of the second-highest level of the vertical slag samples from batch T1 at the settling start (4a) and end (4b). The results of the corresponding EDS point analyses marked with numbers (1-8) in Figure 4 are listed in Table 5.

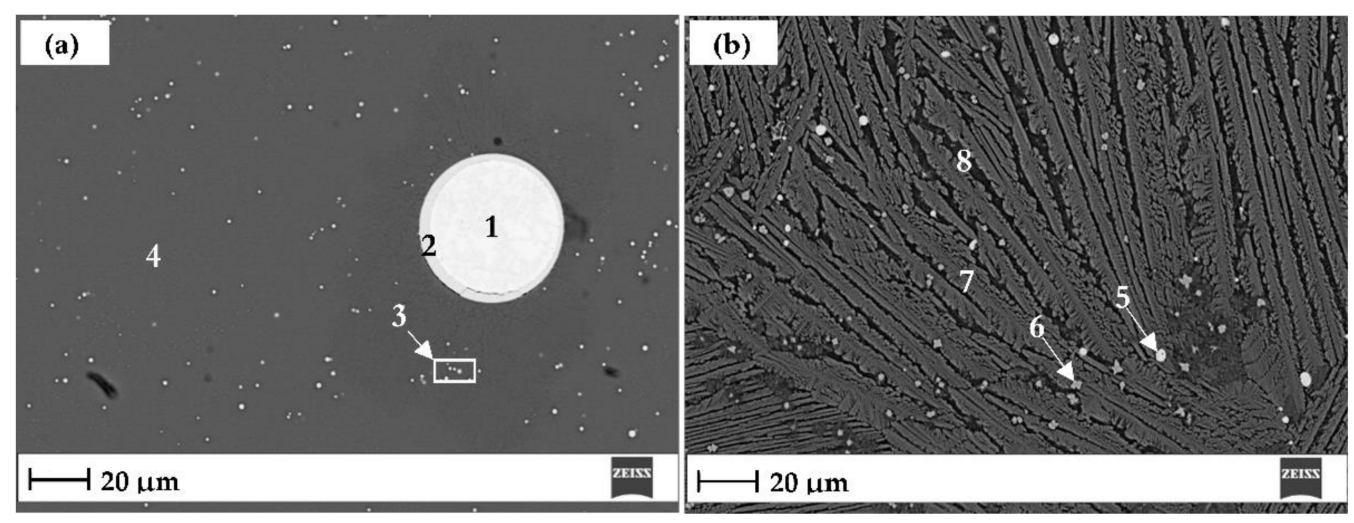

Figure 4. SEM images of slag from level 5 in batch T1 at: (a) the settling start (1L5_T1) where the phase labeled as " 1 " is speiss, " 2 " is matte, " 3 " is the slag phase with copper inclusions, and " 4 " the slag phase; (b) the settling end (2L5_T1) where " 5 " is a matte droplet, " 6 " the chromium spinel, and "7" and " 8 " the slag phase.

Matte and speiss were observed as distinct droplets in all the vertical slag samples analyzed, with sizes of up to $150 \mu \mathrm{m}$. The phase labeled as " 1 " is speiss, which is rich in copper and always associated with nickel, arsenic, tin, and antimony. Matte or dissolved 
copper can be reduced into metallic copper under the reducing conditions in the ZFF. The metallic copper can then attract the associated elements $[9,10]$, forming the metalloid speiss. The phase surrounding the speiss (labeled as " 2 "), and the bright dot labeled as " 5 " is matte, which is rich in copper, sulfur, and iron.

Table 5. Normalized EDS point analysis of samples collected at the settling start and end for T1, phases from Figure 4a,b.

\begin{tabular}{|c|c|c|c|c|c|c|c|c|c|c|c|c|c|c|c|}
\hline \multirow[b]{2}{*}{ No } & \multirow[b]{2}{*}{ Phase } & \multicolumn{14}{|c|}{ [wt \%] } \\
\hline & & O & $\mathrm{Mg}$ & Al & Si & $S$ & $\mathrm{Cr}$ & $\mathrm{Ca}$ & $\mathrm{Fe}$ & $\mathrm{Ni}$ & $\mathrm{Cu}$ & $\mathrm{Zn}$ & As & Sn & $\mathrm{Sb}$ \\
\hline 1 & Speiss & & & & & & & & 3.0 & 12.9 & 63.1 & & 7.9 & 2.6 & 10.5 \\
\hline 2 & Matte & 1.6 & & & 0.4 & 15.2 & & & 4.0 & 3.1 & 70.3 & & 1.2 & 0.6 & 3.6 \\
\hline 3 & Slag, Cu & 30.8 & 0.8 & 2.2 & 18.1 & 1.2 & & 2.8 & 38.2 & & 4.5 & 1.4 & & & \\
\hline 4 & Slag & 33.0 & 0.8 & 2.3 & 18.8 & 0.3 & & 2.9 & 40.3 & & 0.2 & 1.4 & & & \\
\hline 5 & Matte & 4.9 & & & 1.3 & 21.6 & & 0.2 & 11.6 & & 59.4 & 1.0 & & & \\
\hline 6 & Cr spinel & 28.9 & & 3.1 & 6.3 & 0.4 & 8.5 & 0.9 & 50.7 & & & 1.3 & & & \\
\hline 7 & Slag & 32.9 & 1.2 & 1.9 & 18.3 & 0.2 & & 1.7 & 42.4 & & 0.2 & 1.1 & & & \\
\hline 8 & Slag & 37.4 & & 3.7 & 21.3 & 0.5 & & 5.0 & 31.1 & & & 1.1 & & & \\
\hline
\end{tabular}

Small bright areas are present as inclusions in the slag phase, as exemplified by the area marked as " 3 " in Figure 4 a. According to the results of the EDS analysis, areas with and without bright areas mainly differed in copper content, where the copper content of the area with bright dots (" 3 ") was $4.5 \mathrm{wt} \%$, while the area labeled as " 4 " was $0.2 \mathrm{wt} \%$. The bright dots were thus some form of finely dispersed copper and/or matte. The three largest droplets within the area marked as " 3 " have a diameter of between 1.1 and $1.6 \mu \mathrm{m}$.

The droplets could originate from dissolved copper that subsequently precipitated during sample cooling because of the concomitant decrease in copper solubility [11,12]. The finely dispersed droplets could also be produced by the ZFF, which is characterized by a turbulent flow of reducing gases. The microdroplets have a long settling time, attributable to their small size $(\sim 1 \mu \mathrm{m})$.

The slag phase is labeled as " 4 ", " 7 ", and " 8 " and mainly contained the oxidic form of iron and silica and the minor elements ( $>1 \mathrm{wt} \%$ ) calcium, aluminum, zinc, and $0.2-0.3 \mathrm{wt} \%$ copper. The irregular area, labeled as " 6 " in Figure $4 b$, is most probably the nucleation of a chromium-rich spinel at the top of the slag layer, which mainly contains iron, chromium, and silica (called "Cr spinel" in Table 5). The chromium spinel could precipitate in the liquid slag when the chromium content exceeds the chromium solubility, as in the study by Sukhomlinov et al. [31]. The chromium oxide content in the top layer is $0.23 \mathrm{wt} \%$ (Table A2, Appendix A), which could be above the chromium solubility in this slag system.

Figure 5a-c correlate the copper content of the vertical slag samples with their content of antimony, arsenic, and nickel, respectively (data from Table A2). $\mathrm{R}^{2}$ was between 0.82 and 0.83 for the correlation between copper and antimony, arsenic, and nickel. The correlations were positive in all cases, thus indicating the presence of speiss. The EDS analysis of speiss confirmed the positive correlations of the chemical slag compositions.
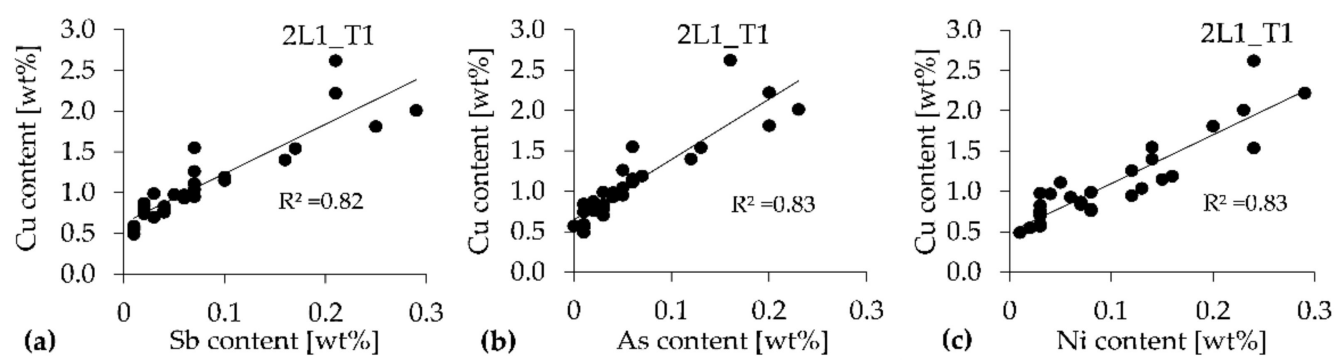

Figure 5. Copper content is plotted against (a) the antimony content; (b) the arsenic content; (c) the nickel content in vertical slag samples. 
Thus, a decrease in slag copper content was concluded to be associated with decreases in antimony, arsenic, and nickel contents. In all plots, the point with the largest deviation corresponds to the sample with the highest copper content and temperature, namely, the bottom-most sample in T1 at the settling end (named 2L1_T1 in Table A2). Granulated slag is often utilized as a construction material, and thus enhanced by a decreased content of copper and the associated elements. However, decreasing the content of the associated elements in the slag will also mean that more of these elements are recovered with the copper phases and possibly recycled internally, increasing the load of these impurity elements.

\section{Factors Hindering Settling in Industrial Slag}

Figure 6a presents a SEM image of the bottom-most samples collected at the settling end from batch T1 (2L1_T1, in Table A2); the results of the corresponding EDS point analyses are presented in Table 6. The chromium-rich phase labeled as "2" has a composition that corresponds to a $(\mathrm{Fe}, \mathrm{Mg}, \mathrm{Zn})(\mathrm{Fe}, \mathrm{Cr}, \mathrm{Al})_{2} \mathrm{O}_{4}$ spinel (named "Cr spinel" in Table 6). Lennartsson et al. have characterized the bottom buildup in the ESF at Boliden Rönnskär, where the dominating phase belonged to a spinel group. It was suggested that the composition of the identified spinels corresponded to a solid solution within the spinel group $\left(\mathrm{FeFe}_{3} \mathrm{O}_{4}, \mathrm{ZnCr}_{2} \mathrm{O}_{4}\right.$, and [ $\left.\left.(\mathrm{Zn}, \mathrm{Mn}, \mathrm{Fe},)(\mathrm{Fe}, \mathrm{Mn})_{2} \mathrm{O}_{4}\right]\right)$, rather than a pure mineral [32]. The ESF slag was treated under reducing conditions in the ZFF and then tapped into the settling furnace, where the samples in this study were collected. The chromium spinel observed in this study is thus most probably a spinel similar to the spinels identified by Lennartsson et al. The chromium spinel was attached to copper phases (marked with "1"), as exemplified in Figure 6a. The chromium spinel was observed at all sample sites for batch T1, always attached to a copper phase, and only present at a few locations in the cases of batches T3 and T4. The thickness of the slag layer surrounding the steel rod during sampling was estimated to be $\sim 5 \mathrm{~mm}$ and thus cooled quickly. The relatively large spinels that were identified in the samples were thus also present in the liquid slag. The chromium solubility in this slag system is most probably below $1.21 \mathrm{wt} \%$, which is the lowest chromium oxide content in the level 1 samples at the settling end.

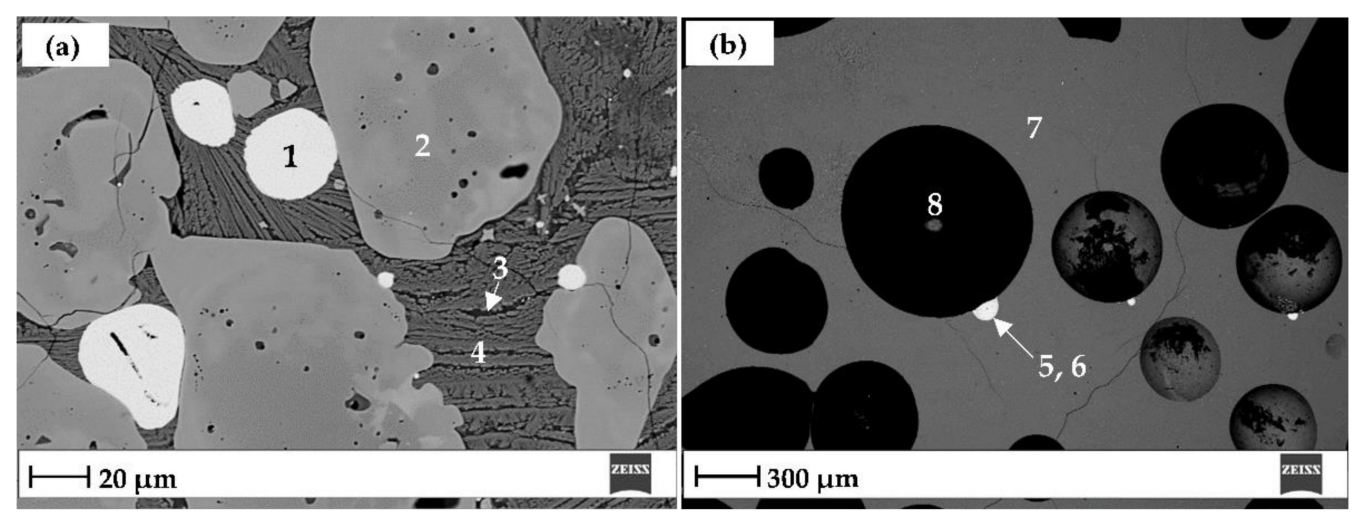

Figure 6. (a) SEM image of slag from level 1 in batch T1 at the settling end where " 1 " is matte, " 2 " the chromium spinel, and " 3 " and " 4 " the slag phase; (b) SEM image of slag from level 5 in batch T4 at the settling start, where " 6 " is matte surrounding speiss, " 5 ", in the bright droplet. " 7 " is the slag phase and " 8 " is a pore caused by a gas bubble.

The attachment of copper to the chromium spinel could contribute to the high copper content of batch T1, as the chromium spinel could be present as a solid, which hinders copper from settling. The density of the copper-spinel entity is lower compared to the underlying copper phases and it can thus not settle to that phase [18]. Still, the settling rate of a copper-spinel entity is higher compared to a single copper droplet (which is smaller in size), which also contributes to the accumulation of the entity in the bottom slag layer.

Figure $6 \mathrm{~b}$ presents an image of a sample from level 5 of batch T4. All the level 5 samples collected at the settling start contained bubbles, which were produced in the ZFF 
prior to the settling process; these bubbles were often associated with copper phases. The darkest phase represents the bubbles (" 8 ") and the slag phase is labeled as "7" in Figure 6b. The brightest phases are matte and speiss, the droplet marked with " 5,6 " is similar to the droplet marked with "1, 2" in Figure 4a, where the matte phase surrounds the speiss phase.

Table 6. Normalized EDS point analysis of samples collected at the settling end for T1 and settling start for T4.

\begin{tabular}{|c|c|c|c|c|c|c|c|c|c|c|c|c|c|c|c|}
\hline \multirow[b]{2}{*}{ No. } & \multirow[b]{2}{*}{ Phase } & \multicolumn{14}{|c|}{ [wt $\%$ ] } \\
\hline & & O & Mg & Al & Si & $S$ & $\mathrm{Ca}$ & $\mathrm{Cr}$ & $\mathrm{Fe}$ & $\mathrm{Ni}$ & $\mathrm{Cu}$ & $\mathrm{Zn}$ & As & Sn & $\mathrm{Sb}$ \\
\hline 1 & Matte & 1.4 & & & 0.2 & 18.8 & & 0.5 & 3.1 & 0.7 & 74.8 & & & & 0.5 \\
\hline 2 & Cr spinel & 25.6 & 0.7 & 5.2 & & & & 34.9 & 29.8 & & 0.1 & 3.7 & & & \\
\hline 3 & Slag & 32.9 & & 4.0 & 21.9 & 1.0 & 6.5 & 0.4 & 30.1 & & 1.6 & 1.6 & & & \\
\hline 4 & Slag & 31.3 & 1.0 & 2.2 & 18.5 & 0.3 & 2.3 & 0.5 & 42.6 & & & 1.3 & & & \\
\hline 5 & Speiss & & & & & & & & 2.7 & 3.3 & 77.0 & & 2.3 & 6.7 & 8.0 \\
\hline 6 & Matte & & & & & 24.6 & & & 11.4 & & 64.0 & & & & \\
\hline 7 & Slag & 28.4 & 1.2 & 2.6 & 20.1 & 0.8 & 3.2 & 0.3 & 41.7 & & & 0.9 & & & \\
\hline
\end{tabular}

The samples collected at the settling end also contained bubbles attached to copper phases. These bubbles could originate from the bottom of the furnace as a result of a chemical reaction. The settling time for the batches was $\sim 30 \mathrm{~min}$, and the bubbles are thus not likely to originate from the ZFF. However, the slag could still contain unreacted coal powder from the fuming process, which could combust forming gas bubbles, or the bubbles could originate from reactions with the graphite electrodes. The attachment of copper to bubbles could hinder settling and instead result in copper ascending through the slag layer, which was in line with the results of Minto and Davenport [3]. Fewer bubbles were observed in the samples collected at the settling end compared to the settling start.

The chromium oxide content at the different slag levels in T1-T4 is presented in Figure 7. The plot reveals that the chromium oxide content increases towards the bottom of the slag layer, most probably due to the presence of the bottom buildup. The chromium oxide content in the upper slag layers (levels 3 and 5) has about the same content as in the average ingoing and outgoing slag $(0.3-0.4 \mathrm{wt} \%)$. The progression of the bottom buildup is most probably because the chromium slag content is higher than the chromium solubility.

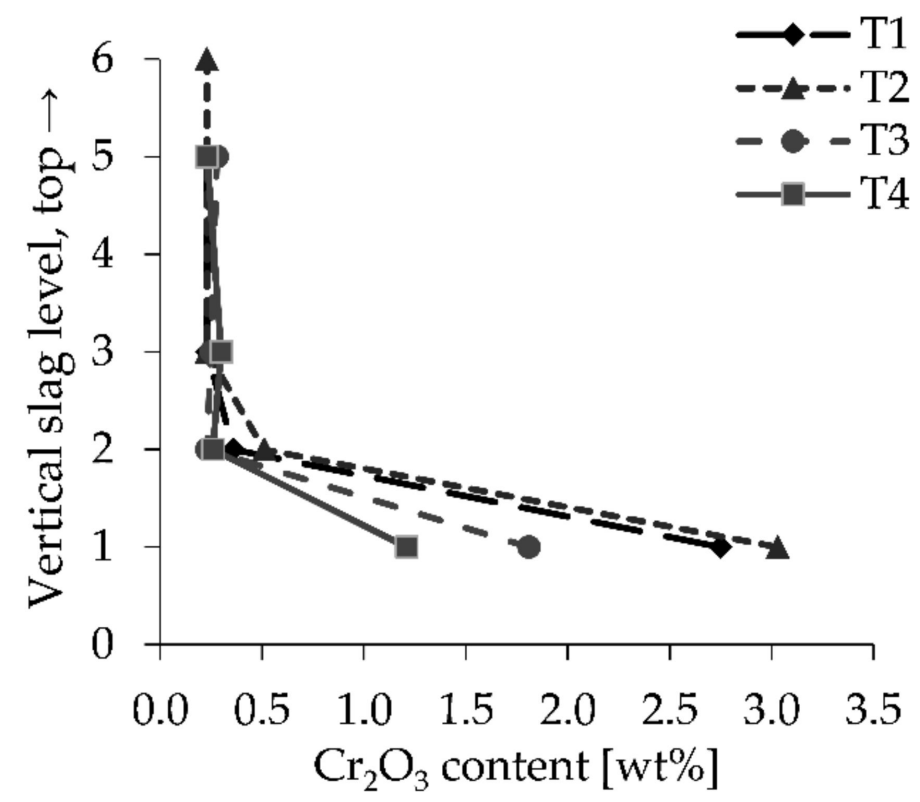

Figure 7. Chromium oxide content at the vertical slag levels in batch T1-T4 at the settling end. 
The chromium oxide content of the level 1 samples was $2.75 \mathrm{wt} \%, 3.03 \mathrm{wt} \%, 1.81 \mathrm{wt} \%$, and $1.21 \mathrm{wt} \%$ in T1, T2, T3, and T4, respectively (Table A2, Appendix A). The frequency of the chromium spinels' appearances in the SEM images was in agreement with the chromium oxide contents of the level 1 samples, which strengthens the indication that the appearance of the chromium spinel was more frequent in the sample from batch T1. At higher temperatures, more of this buildup could melt and mix with the slag in the bottom slag layer and thus increase the chromium oxide content and hence the copper content.

\section{Conclusions}

The settling of copper-containing phases in reduced iron silicate slag was examined in an industrial trial in a settling furnace. The trial was conducted to increase the knowledge of the effect on the slag copper content of the process parameters of temperature and settling time. The results from the study confirmed that the copper content in slag increases with increasing temperatures at the evaluated intervals. The settling process can thus be enhanced for increased copper recovery by monitoring and regulating the temperature to the lower interval. The effect of the settling time on the copper content in the slag was inconclusive as the copper content was more strongly affected by the temperature in the settling furnace. Thus, further investigations of the settling time are needed where the temperature is kept as constant as possible.

The copper in the slag was in the form of speiss (rich in copper, antimony, arsenic, and nickel) and matte, which means that increased copper recovery also results in a decreased content of the associated metals in the slag phase. The final slag product, granulated slag, is enhanced by the decreased content of copper and the associated elements. Still, it will also mean that more of these impurity elements are recovered with the copper phases and possibly recycled internally.

The results from the study also concluded that the copper-containing droplets in industrial slag were hindered from settling due to their attachment to gas bubbles and a chromium-rich spinel in the bottom slag layer. The finding of the attachment to the chromium spinel sheds light on the importance of keeping control of the bottom buildup and solid spinels in the slag phase. Preventing the bottom buildup and solid spinels from forming, or limiting their extent as far as possible, would decrease the attachment to copper phases, thus increasing the recovery. Reducing the presence of the bottom buildup would also increase the working volume in the furnace.

Author Contributions: Conceptualization, J.I., T.V., A.L. and C.S.; formal analysis, J.I. and T.V.; investigation, J.I.; methodology, J.I. and T.V.; supervision, A.L. and C.S.; visualization, J.I.; writingoriginal draft, J.I.; writing-review and editing, J.I., T.V., A.L. and C.S. All authors have read and agreed to the published version of the manuscript.

Funding: The present work was financially supported by Boliden through Bolidenpaketet. The study is conducted within the context of CAMM ${ }^{2}$ (Center of Advanced Mining and Metallurgy) at Luleå University of Technology.

Conflicts of Interest: The authors declare no conflict of interest.

\section{Appendix A}

The compositions of batch T1-T4 are presented in Table A1 with the related standard deviations of copper (st.d $\mathrm{Cu}$ ). The average ingoing slag composition is an average of three samples from each batch. The average outgoing slag composition is an average of five to six samples from each batch.

The chemical compositions of the vertical slag samples are shown in Table A2. The samples are named XLY_ZZ. X corresponds to the time when the sample was collected, settling start (1), or the settling end (2). LY relates to the sample level (level $Y=L Y$ ), and ZZ explains the batch number (T1-T4). 
Table A1. The chemical composition of average ingoing (ing.) and outgoing (out.) slag and the water-granulated slag (w.g), and the related standard deviations of copper (st.d $\mathrm{Cu}$ ).

\begin{tabular}{|c|c|c|c|c|c|c|c|c|c|c|c|}
\hline & & & & & & [wt $\%]$ & & & & & \\
\hline Batch & Sample & $\mathrm{SiO}_{2}$ & $\mathrm{FeO}$ & $\mathrm{Al}_{2} \mathrm{O}_{3}$ & $\mathrm{CaO}$ & MgO & $\mathrm{Cr}_{2} \mathrm{O}_{3}$ & $\mathrm{ZnO}$ & $\mathrm{Sb}$ & $\mathrm{Cu}$ & St.d Cu \\
\hline \multirow{3}{*}{$\mathrm{T} 1$} & ing. & 37.51 & 49.47 & 4.69 & 4.33 & 1.29 & 0.28 & 1.20 & 0.08 & 1.14 & 0.18 \\
\hline & out. & 38.55 & 48.85 & 4.91 & 4.01 & 1.40 & 0.32 & 1.30 & 0.02 & 0.63 & 0.02 \\
\hline & w.g. & 38.20 & 48.46 & 4.46 & 4.03 & 1.84 & 0.31 & 1.43 & 0.02 & 1.25 & - \\
\hline \multirow{3}{*}{$\mathrm{T} 2$} & ing. & 37.35 & 49.63 & 5.17 & 3.50 & 1.41 & 0.33 & 1.22 & 0.06 & 1.32 & 0.07 \\
\hline & out. & 37.84 & 49.64 & 4.95 & 3.41 & 1.38 & 0.34 & 1.55 & 0.03 & 0.85 & 0.08 \\
\hline & w.g. & 38.61 & 48.58 & 4.64 & 3.48 & 1.94 & 0.32 & 1.39 & 0.03 & 1.00 & - \\
\hline \multirow{3}{*}{ T3 } & ing. & 38.35 & 48.61 & 4.78 & 4.36 & 1.48 & 0.32 & 1.00 & 0.07 & 1.02 & 0.08 \\
\hline & out. & 39.06 & 47.65 & 5.25 & 4.18 & 1.55 & 0.32 & 1.33 & 0.04 & 0.62 & 0.03 \\
\hline & w.g. & 38.50 & 48.43 & 4.49 & 4.38 & 1.81 & 0.31 & 1.34 & 0.02 & 0.71 & - \\
\hline \multirow{3}{*}{$\mathrm{T} 4$} & ing. & 36.79 & 49.84 & 4.85 & 4.73 & 1.59 & 0.40 & 0.73 & 0.04 & 1.03 & 0.09 \\
\hline & out. & 38.64 & 48.32 & 5.38 & 4.36 & 1.62 & 0.36 & 0.83 & 0.02 & 0.46 & 0.02 \\
\hline & w.g. & 38.91 & 48.38 & 4.44 & 4.55 & 1.87 & 0.35 & 0.88 & 0.06 & 0.55 & - \\
\hline
\end{tabular}

Table A2. Normalized chemical composition of vertical slag samples from batch T1-T4.

\begin{tabular}{|c|c|c|c|c|c|c|c|c|c|c|c|c|c|}
\hline & & & & & & [wt \%] & & & & & & & \\
\hline Batch & $\mathrm{SiO}_{2}$ & $\mathrm{FeO}$ & $\mathrm{Al}_{2} \mathrm{O}_{3}$ & $\mathrm{CaO}$ & $\mathrm{MgO}$ & $\mathrm{Cr}_{2} \mathrm{O}_{3}$ & $\mathrm{ZnO}$ & As & $S$ & $\mathbf{N i}$ & Sn & $\mathrm{Sb}$ & $\mathrm{Cu}$ \\
\hline 1L5_T1 & 35.11 & 52.38 & 4.09 & 3.42 & 1.15 & 0.23 & 1.56 & 0.07 & 0.34 & 0.16 & 0.20 & 0.10 & 1.19 \\
\hline 1L3_T1 & 38.02 & 49.43 & 4.41 & 3.66 & 1.27 & 0.23 & 1.56 & 0.03 & 0.32 & 0.08 & 0.17 & 0.04 & 0.78 \\
\hline 1L2_T1 & 36.17 & 51.36 & 4.31 & 3.77 & 1.18 & 0.22 & 1.58 & 0.02 & 0.33 & 0.08 & 0.18 & 0.04 & 0.76 \\
\hline 1L1_T1 & 35.11 & 52.15 & 4.17 & 3.58 & 1.22 & 0.26 & 1.70 & 0.05 & 0.34 & 0.13 & 0.19 & 0.07 & 1.04 \\
\hline 2L5_T1 & 35.06 & 52.33 & 4.09 & 3.46 & 1.20 & 0.23 & 1.61 & 0.06 & 0.35 & 0.15 & 0.19 & 0.10 & 1.15 \\
\hline 2L3_T1 & 38.33 & 49.23 & 4.19 & 3.49 & 1.24 & 0.23 & 1.56 & 0.05 & 0.34 & 0.12 & 0.19 & 0.07 & 0.95 \\
\hline 2L2_T1 & 35.56 & 50.46 & 4.42 & 3.84 & 1.17 & 0.36 & 1.53 & 0.13 & 0.39 & 0.24 & 0.20 & 0.17 & 1.54 \\
\hline 2L1_T1 & 33.78 & 47.94 & 4.94 & 3.52 & 1.40 & 2.75 & 1.62 & 0.16 & 0.62 & 0.24 & 0.2 & 0.21 & 2.62 \\
\hline 1L6_T2 & 38.50 & 49.29 & 4.23 & 3.23 & 1.34 & 0.24 & 1.69 & 0.01 & 0.38 & 0.07 & 0.14 & 0.02 & 0.84 \\
\hline 1L3_T2 & 39.28 & 48.64 & 4.21 & 3.17 & 1.26 & 0.22 & 1.74 & 0.02 & 0.39 & 0.07 & 0.15 & 0.02 & 0.84 \\
\hline 1L2_T2 & 37.60 & 48.26 & 4.93 & 3.02 & 1.33 & 1.15 & 1.62 & 0.05 & 0.43 & 0.12 & 0.16 & 0.07 & 1.26 \\
\hline 1L1_T2 & 34.85 & 47.58 & 4.71 & 2.99 & 1.44 & 4.17 & 1.73 & 0.06 & 0.55 & 0.14 & 0.16 & 0.07 & 1.55 \\
\hline 2L6_T2 & 38.67 & 49.00 & 4.24 & 3.31 & 1.26 & 0.23 & 1.76 & 0.02 & 0.40 & 0.07 & 0.15 & 0.02 & 0.87 \\
\hline 2L3_T2 & 37.45 & 50.32 & 4.24 & 3.19 & 1.25 & 0.23 & 1.82 & 0.02 & 0.39 & 0.07 & 0.15 & 0.02 & 0.85 \\
\hline 2L2_T2 & 38.41 & 48.59 & 4.74 & 3.12 & 1.33 & 0.51 & 1.64 & 0.03 & 0.39 & 0.08 & 0.15 & 0.03 & 0.99 \\
\hline 2L1_T2 & 34.76 & 48.31 & 4.34 & 2.89 & 1.30 & 3.03 & 1.72 & 0.20 & 0.50 & 0.29 & 0.21 & 0.21 & 2.22 \\
\hline 1L5_T3 & 36.19 & 49.62 & 4.17 & 3.58 & 1.27 & 0.24 & 1.46 & 0.23 & 0.58 & 0.23 & 0.14 & 0.29 & 2.01 \\
\hline 1L3_T3 & 39.30 & 47.46 & 4.29 & 3.53 & 1.37 & 0.24 & 1.34 & 0.12 & 0.52 & 0.14 & 0.13 & 0.16 & 1.40 \\
\hline 1L2_T3 & 37.34 & 48.41 & 4.38 & 3.78 & 1.27 & 0.24 & 1.38 & 0.20 & 0.59 & 0.20 & 0.15 & 0.25 & 1.81 \\
\hline 1L1_T3 & 37.09 & 48.81 & 4.47 & 3.69 & 1.40 & 1.39 & 1.45 & 0.04 & 0.47 & 0.06 & 0.12 & 0.06 & 0.93 \\
\hline 2L5_T3 & 37.50 & 49.88 & 4.46 & 4.17 & 1.50 & 0.28 & 0.90 & 0.01 & 0.73 & 0.01 & 0.05 & 0.01 & 0.49 \\
\hline 2L3_T3 & 40.17 & 47.32 & 4.52 & 3.77 & 1.45 & 0.25 & 1.36 & 0.00 & 0.44 & 0.03 & 0.11 & 0.01 & 0.57 \\
\hline 2L2_T3 & 38.29 & 49.09 & 4.59 & 3.86 & 1.31 & 0.23 & 1.41 & 0.01 & 0.46 & 0.03 & 0.12 & 0.01 & 0.59 \\
\hline 2L1_T3 & 37.09 & 48.62 & 4.55 & 3.64 & 1.36 & 1.81 & 1.54 & 0.01 & 0.47 & 0.03 & 0.12 & 0.02 & 0.74 \\
\hline 1L6_T4 & 36.80 & 50.01 & 4.41 & 4.20 & 1.48 & 0.28 & 0.84 & 0.04 & 0.78 & 0.03 & 0.10 & 0.05 & 0.98 \\
\hline 1L3_T4 & 37.63 & 49.55 & 4.37 & 3.60 & 1.52 & 0.31 & 0.88 & 0.06 & 0.73 & 0.05 & 0.11 & 0.07 & 1.11 \\
\hline 1L2_T4 & 36.50 & 50.44 & 4.48 & 3.90 & 1.43 & 0.54 & 0.91 & 0.03 & 0.77 & 0.03 & 0.09 & 0.04 & 0.83 \\
\hline 1L1_T4 & 35.95 & 48.47 & 4.79 & 3.93 & 1.53 & 2.44 & 0.98 & 0.04 & 0.70 & 0.04 & 0.10 & 0.06 & 0.97 \\
\hline 2L5_T4 & 37.28 & 49.35 & 5.15 & 3.86 & 1.68 & 0.23 & 1.23 & 0.01 & 0.54 & 0.02 & 0.10 & 0.01 & 0.55 \\
\hline 2L3_T4 & 38.65 & 48.58 & 4.65 & 4.07 & 1.58 & 0.30 & 0.88 & 0.01 & 0.72 & 0.01 & 0.06 & 0.01 & 0.49 \\
\hline 2L2_T4 & 36.91 & 50.15 & 4.53 & 4.15 & 1.46 & 0.26 & 0.91 & 0.03 & 0.77 & 0.03 & 0.08 & 0.03 & 0.70 \\
\hline 2L1_T4 & 37.40 & 48.42 & 4.54 & 4.21 & 1.59 & 1.21 & 1.03 & 0.02 & 0.70 & 0.03 & 0.08 & 0.02 & 0.76 \\
\hline
\end{tabular}




\section{References}

1. Schlesinger, M.E.; King, M.J.; Sole, K.C.; Davenport, W.G. Extractive Metallurgy of Copper, 5th ed.; Elsevier Ltd.: Oxford, UK, 2011; ISBN 978-0-08-096789-9.

2. Lotfian, S.; Vikström, T.; Lennartsson, A.; Björkman, B.; Ahmed, H.; Samuelsson, C. Plastic-containing materials as alternative reductants for base metal production. Can. Metall. Q. 2019, 58, 164-176. [CrossRef]

3. Minto, R.; Davenport, W.G. Entrapment and flotation of matte in molten slag. Can. Min. Metall. Bull. 1971, 65, 70-76.

4. Ip, S.W.; Toguri, J.M. Entrainment Behavior of Copper and Copper Matte in Copper Smelting Operations. Metall. Trans. B 1992, 23, 303-311. [CrossRef]

5. Bellemans, I.; De Wilde, E.; Moelans, N.; Verbeken, K. Metal losses in pyrometallurgical operations-A review. Adv. Colloid Interface Sci. 2018, 255, 47-63. [CrossRef]

6. Zivkovic, Z.; Djordjevic, P.; Mitevska, N. Contribution to the Examination of the Mechanisms of Copper Loss with the Slag in the Process of Sulfide Concentrates Smelting. Mining Metall. Explor. 2019, 48, 143-151. [CrossRef]

7. Cheng, X.; Cui, Z.; Contreras, L.; Chen, M.; Nguyen, A.; Zhao, B. Matte Entrainment by SO2 Bubbles in Copper Smelting Slag. JOM 2019, 71, 1897-1903. [CrossRef]

8. Genevski, K.; Stefanova, V. DISPERSED MATTE DROPLETS IN INDUSTRIAL SLAG MELTS FROM FLASH SMELTING FURNACE. Can. Metall. Q. 2008, 47, 51-58. [CrossRef]

9. Lynch, D.C.; Akagi, S.; Davenport, W.G. Thermochemical Nature of Minor Elements in Copper Smelting Mattes. Metall. Trans. B 1991, 22, 677-688. [CrossRef]

10. Nagamori, M.; Mackey, P.J.; Tarassoff, P. Copper Solubility in FeO-Fe2O3-SiO2-Al2O3 Slag and Distribution Equilibria of Pb, Bi, $\mathrm{Sb}$ and As Between Slag and Metallic Copper. Metall. Trans. B 1975, 6, 295-301. [CrossRef]

11. Jalkanen, H.; Vehviläinen, J.; Poijärvi, J. Copper in solidified copper smelter slags. Scand. J. Metall. 2003, 32, 65-70. [CrossRef]

12. Coursol, P.; Valencia, N.C.; Mackey, P.; Bell, S.; Davis, B. Minimization of Copper Losses in Copper Smelting Slag During Electric Furnace Treatment. JOM 2012, 64, 1305-1313. [CrossRef]

13. Mackey, P.J. THE PHYSICAL CHEMISTRY OF COPPER SMELTING SLAGS-A REVIEW. Can. Metall. Q. 1982, 21, 221-260. [CrossRef]

14. Zhao, Z.; Wang, Z.; Peng, N.; Peng, B.; Liang, Y.; Qu, S.; Dong, Z.; Zeng, W. Copper Behavior and Fayalite Microstructure Changes Influenced by Cu2O Dissolution. JOM 2019, 71, 2891-2898. [CrossRef]

15. Shishin, D.; Jak, E.; Decterov, S.A. Thermodynamic Assessment of Slag-Matte-Metal Equilibria in the Cu-Fe-O-S-Si System. J. Phase Equilib. Diffus. 2018, 39, 456-475. [CrossRef]

16. Nagamori, M.; Mackey, P.J. Thermodynamics of Copper Matte Converting: Part I. Fundamentals of the Noranda Process. Metall. Trans. B 1978, 9, 255-265. [CrossRef]

17. Shimpo, R.; Goto, S.; Ogawa, O.; Asakura, I. A Study on the Equilibrium Between Copper Matte and Slag. Can. Metall. Q. 1986, 25, 113-121. [CrossRef]

18. Sridhar, R.; Toguri, J.M.; Simeonov, S. Copper Losses and Thermodynamic Considerations in Copper Smelting. Metall. Mater. Trans. B 1997, 28, 191-200. [CrossRef]

19. Toguri, J.M.; Santander, N.H. The solubility of copper in fayalite slags at $1300^{\circ} \mathrm{C}$. Can. Metall. Q. 1969, 8, 167-171. [CrossRef]

20. Nagamori, M. Metal Loss to Slag: Part 1. Sulfidic and Oxidic Dissolution of Copper in Fayalite Slag from Low Grade Matte. Metall. Trans. 1974, 5, 531-538. [CrossRef]

21. Kim, H.G.; Sohn, H.Y. Effects of $\mathrm{CaO}, \mathrm{Al2O} 3$, and MgO Additions on the Copper Solubility, Ferric/Ferrous Ratio, and MinorElement Behavior of Iron-Silicate Slags. Metall. Mater. Trans. B 1998, 29, 583-590. [CrossRef]

22. Fallah-Mehrjardi, A.; Hayes, P.C.; Jak, E. The Effect of CaO on Gas/Slag/Matte/Tridymite Equilibria in Fayalite-Based Copper Smelting Slags at $1473 \mathrm{~K}\left(1200{ }^{\circ} \mathrm{C}\right)$ and $\mathrm{P}(\mathrm{SO} 2)=0.25 \mathrm{~atm}$. Metall. Mater. Trans. B 2018, 49, 602-609. [CrossRef]

23. Toguri, J.M.; Santander, N.H. Distribution of Copper Between Cu-Au Alloys and Silica-Saturated Fayalite Slags. Metall. Trans. 1972, 3, 586-588. [CrossRef]

24. Park, H.-S.; Park, S.S.; Sohn, I. The Viscous Behavior of FeOt-Al2O3-SiO2 Copper Smelting Slags. Metall. Mater. Trans. B 2011, 42, 692-699. [CrossRef]

25. Huang, A.; Huo, Y.; Yang, J.; Gu, H.; Li, G. Computational Modeling and Prediction on Viscosity of Slags by Big Data Mining. Minerals 2020, 10, 257. [CrossRef]

26. Deng, L.; Wang, S.; Zhang, Z.; Li, Z.; Jia, R.; Yun, F.; Li, H.; Ma, Y.; Wang, W. The viscosity and conductivity of the molten glass and crystallization behavior of the glass ceramics derived from stainless steel slag. Mater. Chem. Phys. 2020, 251, 1-9. [CrossRef]

27. Bellemans, I.; De Wilde, E.; Claeys, L.; De Seranno, T.; Campforts, M.; Blanpain, B.; Moelans, N.; Verbeken, K. Investigation of Reactive Origin for Attachment of Cu Droplets to Solid particles. Metall. Mater. Trans. B 2017, 48, 2459-2468. [CrossRef]

28. Bellemans, I.; Cnockaert, V.; De Wilde, E.; Moelans, N.; Verbeken, K. Metal Droplet Entrainment by Solid Particles in Slags: An Experimental Approach. J. Sustain. Metall. 2018, 4, 15-32. [CrossRef]

29. De Wilde, E.; Bellemans, I.; Zheng, L.; Campforts, M.; Guo, M.; Blanpain, B.; Moelans, N.; Verbeken, K. Origin and sedimentation of Cu-droplets sticking to spinel solids in pyrometallurgical slags. Mater. Sci. Technol. 2016, 32, 1911-1924. [CrossRef]

30. Bellemans, I.; De Wilde, E.; Moelans, N.; Verbeken, K. Phase field simulation study of the attachment of metallic droplets to solid particles in liquid slags based on real slag-spinel micrographs. Comput. Mater. Sci. 2016, 118, 269-278. [CrossRef] 
31. Sukhomlinov, D.; Avarmaa, K.; Virtanen, O.; Taskinen, P.; Jokilaakso, A. Slag-Copper Equilibria of Selected Trace Elements in Black Copper Smelting. Part I. Properties of the Slag and Chromium Solubility. Miner. Process. Extr. Metall. Rev. 2020, 41, 32-40. [CrossRef]

32. Lennartsson, A.; Engström, F.; Björkman, B.; Samuelsson, C. Characterisation of buildup in an electric furnace for smelting copper concentrate. Can. Metall. Q. 2015, 54, 477-484. [CrossRef]

33. Tan, P. Modeling and control of copper loss in smelting slag. JOM 2011, 63, 51-57. [CrossRef]

34. Fagerlund, K.O.; Jalkanen, H. Microscale simulation of settler processes in copper matte smelting. Metall. Mater. Trans. B 2000, 31, 439-451. [CrossRef] 